\title{
Mechanisms of Killing of Newborn Larvae of Trichinella spiralis by Neutrophils and Eosinophils
}

\author{
KILLING BY GENERATORS OF HYDROGEN PEROXIDE IN VITRO
}

\author{
David A. Bass and Pamela Szejda, Department of Medicine, \\ Bowman Gray School of Medicine, Winston-Salem, \\ North Carolina 27103
}

A B S T RACT Eosinophil and/or neutrophil leukocytes appear to have important roles in host defense against invasive, migratory helminth infestations, but the mechanisms of larval killing by leukocytes are uncertain. This study examines killing of newborn (migratory phase) larvae of Trichinella spiralis during incubation with granule preparations of human eosinophils or neutrophils and generators of hydrogen peroxide (glucose-glucose oxidase) (G-GO) or superoxide and hydrogen peroxide (xanthine-xanthine oxidase). Larvae were killed by either hydrogen peroxidegenerating system in a concentration-dependent manner. Direct enumeration of surviving larvae after incubation in microtiter wells containing the appropriate reagents was used in assess larval kiliing. Verification of the microplate assay was demonstrated by complete loss of larval ability to incorporate $\left[{ }^{3} \mathrm{H}\right]$ deoxyglucose and loss of infectivity after incubation in comparable concentrations of G-GO. Larvae were highly sensitive to oxidative products; significant killing occurred after incubation with $0.12 \mathrm{mU}$ glucose oxidase and complete killing occurred with $0.5 \mathrm{mU}$. Comparable killing of bacteria required over $60 \mathrm{mU}$ glucose oxidase. At $5 \mathrm{mU}$ glucose oxidase, killing was complete after $6 \mathrm{~h}$ of incubation. Killing by G-GO was inhibited by catalase but not by boiled catalase or superoxide dismutase and was enhanced by azide. Addition of peroxidase in granule pellet preparations of eosinophils or neutrophils did not enhance killing by G-GO. These data indicate a remarkable susceptibility of newborn larvae of $T$. spiralis to the hydrogen peroxide generated by neutrophil and eosinophil leukocytes.

\section{INTRODUCTION}

Host defenses against invasive metazoan parasites are currently subjects of active study. Recent reports

Received for publication 21 February 1979 and in revised form 20 August 1979. have suggested major roles for eosinophils (1-6), neutrophils (5-7), macrophages $(8,9)$, and/or mast cells (10) in immune responses to Schistosoma mansoni or Trichinella spiralis. The mechanisms of larval killing in these various systems are largely unexplored.

David et al. (11) examined the effects of metabolic inhibitors on eosinophil-mediated damage of schistosomula as monitored by release of chromium- 51 . Chromium release was not prevented by inhibitors of DNA or protein synthesis, aerobic metabolism, microtubule aggregation, or prostaglandin synthesis. Inhibitors of glycolysis or microfilament function prevented chromium release. Butterworth et al. (12) recently reported that purified eosinophil "major basic protein" (MBP) 1 can damage schistosomula of $S$. mansoni. The efficiency of damage by MBP appeared $\sim 10$-fold less than that of intact eosinophils. Also, whereas heparin abolished the release of chromium-51 induced by MBP, heparin had no effect on chromium release induced by intact cells.

We recently examined killing of newborn larvae of $T$. spiralis by human leukocytes (5). Results with metabolic inhibitors were similar to those found by David et al. (11). Also, killing was inhibited by catalase but not by superoxide dismutase. Azide and cyanide should block the peroxidase- $\mathrm{H}_{2} \mathrm{O}_{2}$-halide bactericidal mechanism of leukocytes (13), yet they actually enhanced larval killing. Moreover, leukocytes from a patient with chronic granulomatous disease, lacking normal oxidative metabolic responses to membrane stimuli, demonstrated markedly impaired and delayed larval killing. These studies suggested that the

\footnotetext{
${ }^{1}$ Abbreviations used in this paper: G-GO, glucose plus glucose oxidase; MBP, major basic protein; MEM/FCS, Eagle's minimal essential medium supplemented with $10 \%$ fetal calf serum, penicillin, gentamicin, and mycostatin; PBS, phosphate-buffered saline; SOD, superoxide dismutase; $\mathrm{X}-\mathrm{XO}$, xanthine plus xanthine oxidase.
} 
major larvicidal mechanism involved the oxidative metabolic burst with production of hydrogen peroxide.

This study examined the susceptibility of newborn larvae of $T$. spiralis to killing by hydrogen peroxide or superoxide. The effects of granule preparations from eosinophils and neutrophils were studied to examine further the role (or lack thereof) of the peroxidase $-\mathrm{H}_{2} \mathrm{O}_{2}$-halide system in larval killing.

\section{METHODS}

Larval preparation. Newborn larvae of $T$. spiralis were isolated by the modified method of Dennis et al. (14) as previously described (5). Briefly, rats were given a large oral inoculum of muscle stage larvae. After $6 \mathrm{~d}$, the intestines were removed and the adult larvae isolated. These were incubated in vitro for $20 \mathrm{~h}$ to allow shedding of the newborn larvae. The newborn larvae were isolated in $100 \%$ purity by passing the medium through a fine mesh. The larvae were washed, quantitated, and suspended at the desired concentration in Eagle's minimal essential medium supplemented with $10 \%$ fetal calf serum, $200 \mathrm{U} / \mathrm{ml}$ penicillin, $50 \mu \mathrm{g} / \mathrm{ml}$ gentamicin, and $100 \mathrm{U} / \mathrm{ml}$ mycostatin (MEM/FCS) (Grand Island Biological Co., Grand Island, N. Y.).

Leukocyte preparation. Heparinized blood was obtained from normal volunteers or patients with eosinophilia and the leukocytes isolated by sedimentation over Ficoll (Pharmacia Fine Chemicals, Inc., Piscataway, N. J.) -metrizoate as previously described (15). Eosinophils from patients with the hypereosinophilic syndrome, eosinophilic gastroenteritis, and acute allergic vasculitis were obtained in $>95 \%$ purity by centrifugation over a linear gradient of sodium metrizamide (Gallard-Schlesinger Chemical Mfg. Corp., Carle Place, N. Y.) as described previously (5). Neutrophil preparations contained $<2 \%$ eosinophils. Erythrocytes were removed by brief hypotonic lysis. The leukocytes were centrifuged, resuspended in $0.34 \mathrm{M}$ sucrose, and homogenized for $5 \mathrm{~min}$ to provide $>90 \%$ breakage as previously described $(16,17)$. The homogenate was centrifuged at $500 \mathrm{~g}$ for $10 \mathrm{~min}$ to remove nuclei and large debris, and the supernate was then centrifuged at $27,000 \mathrm{~g}$ for $15 \mathrm{~min}$. The pellets were resuspended in phosphate-buffered saline (PBS). Protein content of the preparation was measured by the method of Lowry et al. (18). Peroxidase content was measured using $o$-dianisidine (Sigma Chemical Co., St. Louis, Mo.) as substrate as previously described $(19,20)$. One unit of activity is that causing an increase in absorbancy of $0.001 / \mathrm{min}$ at $460 \mathrm{~nm}$ in a Beckman DU spectrophotometer (Beckman Instruments Inc., Fullerton, Calif.) (21). This procedure provided preparations that contained peroxidase in a form capable of interacting in peroxidase $-\mathrm{H}_{2} \mathrm{O}_{2}$-halide killing assays (22). Although the preparations undoubtedly contained organelles other than lysosomes, they are referred to as the "granule pellet," for convenience. The preparations from eosinophils and neutrophils contained peroxidase activities of $1,100-5,800$ and $1,450-4,250 \mathrm{U} / \mathrm{mg}$ protein, respectively. This is equivalent to the relative concentrations of peroxidase in intact eosinophils and neutrophils with $o$-dianisidine employed as substrate (19). Repeated freeze-thawing to lyse intact granules and release any latent enzyme activity, did not alter the activity of the preparations in the killing assays.

Larvicidal assay. Killing of newborn larvae was studied by modification (5) of the technique of Kazura and Grove (2). To each well of flat-bottomed microtiter plates (Linbro Chemical Co., Hamden, Conn.) the following were added: $100 \mu \mathrm{l}$ of larval suspension that contained 30-40 larvae, 10- $\mu$ l supplements that contained desired reagents (leukocyte preparation, enzymes, substrates, inhibitors, etc.), and sufficient MEM/FCS to provide a final volume of $200 \mu \mathrm{l}$. The number of viable larvae in each well was counted at the beginning of each experiment by direct observation with an inverted microscope. Unless specified otherwise, all incubations were for $18 \mathrm{~h}$ at $37^{\circ} \mathrm{C}$ in a $5 \% \mathrm{CO}_{2}, 100 \%$ humidity atmosphere, and assays were conducted at $\mathrm{pH}$ 7.4. After incubation, viable larvae were again counted and the percent killed determined. In this system, dead larvae were not completely lysed; many were immobile and highly refractile but grossly intact.

Reagents. As indicated in the separate experiments, the following reagents were incorporated into the killing assay: glucose oxidase (fungal, Type V, $200 \mathrm{U} / \mathrm{mg}$ protein), xanthine oxidase (buttermilk, $0.5 \mathrm{U} / \mathrm{mg}$ protein), xanthine and catalase (bovine liver, 14,400 U/mg) (all from Sigma Chemical Co.); superoxide dismutase (over 3,000 U/mg) (Truett Laboratories, Dallas, Tex.); heparin sodium (preservative free, $144 \mathrm{U} / \mathrm{mg}$ ), potassium iodide, sodium cyanide or sodium azide (Fisher Scientific Co., Pittsburgh, Pa.). In each experiment, solutions of the reagents in PBS were diluted in MEM/FCS such that $10 \mu \mathrm{l}$ would contain the desired concentration per assay.

Larval uptake of $\left[{ }^{3} \mathrm{H}\right]$ deoxyglucose. The ability of larvae to take up deoxyglucose was examined as a monitor of larval viability. 50,000 larvae were incubated for $18 \mathrm{~h}$ in $10 \mathrm{ml}$ of MEM/FCS or the same medium supplemented with $5 \mathrm{mU} / \mathrm{ml}$ glucose oxidase. The larvae were then washed twice with PBS, resuspended in $5 \mathrm{ml}$ of PBS, and divided into 0.5or $1.0-\mathrm{ml}$ aliquots to provide 5,000 or 10,000 larvae per test. The volume was adjusted to $1.0 \mathrm{ml}$ with $\mathrm{PBS}$ and $10 \mu \mathrm{Ci}$ (0.04 mg) $\left[{ }^{3} \mathrm{H}\right]$ deoxyglucose (New England Nuclear, Boston, Mass.) added in $0.1 \mathrm{ml}$ of PBS. The larvae were incubated with end-over-end rotation at $37^{\circ} \mathrm{C}$ for the indicated times $(0-30 \mathrm{~min})$, and the reaction was stopped by addition of 10 $\mathrm{ml}$ of cold MEM. The larvae were washed twice in $100 \mathrm{vol}$ of cold PBS. The washed larval pellet $(0.1 \mathrm{ml})$ was added to $10 \mathrm{ml}$ Aquasol (New England Nuclear) and counted for 10 min in a Beckman liquid scintillation counter (Beckman Instruments Inc., Spinco Div., Palo Alto, Calif.). The finalwash supernate contained $29-37 \mathrm{cpm} / 0.1 \mathrm{ml}$.

Larval infectivity. The ability of newborn larvae to achieve muscle encystment in normal mice provided another indicator of larval viability. 70,000 larvae were incubated for $8 \mathrm{~h}$ in $12 \mathrm{ml}$ of MEM/FCS or the same medium supplemented with $5 \mathrm{mU} / \mathrm{ml}$ glucose oxidase. The larvae were washed twice and resuspended in $2 \mathrm{ml}$ of MEM/FCS. Aliquots of $0.2 \mathrm{ml}$ were injected into the tail vein of normal C3H/HeJ mice (The Jackson Laboratory, Bar Harbor, Maine). $1 \mathrm{~m}$ later, the mice were sacrificed, skinned, and eviscerated, and the musculoskeletal tissues were homogenized and digested for $4 \mathrm{~h}$ at $37^{\circ} \mathrm{C}$ in acid-pepsin $(7 \mathrm{ml}$ concentrated $\mathrm{HCl}$ and $5 \mathrm{~g}$ pepsin [Fisher Scientific Co.] per liter). The digested material was concentrated to $10 \mathrm{ml}$ by centrifugation, thoroughly shaken, $0.2-\mathrm{ml}$ aliquots taken, and the number of larvae present were counted in triplicate.

Bactericidal assay. Killing of S. aureus 502A under conditions used in these assays was examined as previously described (22). The assay was performed in a volume of 2.0 $\mathrm{ml}$ of PBS that contained $2 \times 10^{7}$ bacteria, $5 \mu \mathrm{g} / \mathrm{ml}$ leukocyte pellet protein, and the indicated concentration of glucose oxidase. In one series of experiments, the reaction was conducted at $\mathrm{pH} 7.4$ in MEM/FCS that contained $119 \mathrm{mM}$ chloride and $10 \mu \mathrm{M}$ iodide. In the other series, the reaction was conducted at $\mathrm{pH} 5.0$ in $0.1 \mathrm{M}$ sodium acetate buffer that contained $0.1 \%$ gelatin, $1 \mathrm{mM}$ chloride, and $10 \mu \mathrm{M}$ iodide. The assay tubes were rotated end-over-end at $37^{\circ} \mathrm{C}$ 
for $60 \mathrm{~min}$, and viable bacteria were determined by the pour-plate method.

Statistical analysis. In all experiments, each determination represents the mean of 3-6 assays. Each experiment was repeated at least three times with similar results. Significance was examined employing the Student's $t$ test.

\section{RESULTS}

Larval killing by generators of hydrogen peroxide and superoxide. Glucose plus glucose oxidase (G-GO), a generator of hydrogen peroxide, or xanthine plus xanthine oxidase (X-XO), a generator of superoxide and hydrogen peroxide (23), caused larval killing in the microplate assay. The degree of killing was dependent upon the concentration of enzyme when substrate was in excess (Fig. 1). Significant killing occurred with $0.12 \mathrm{mU}$ of glucose oxidase, and $99 \%$ killing occurred with $0.5 \mathrm{mU}$ of glucose oxidase per $0.2-\mathrm{ml}$ assay well. If xanthine oxidase was in excess $(63$ $\mathrm{mU} / 0.2-\mathrm{ml}$ assay), killing was related to substrate concentration; $750 \mu \mathrm{M}, 75 \mu \mathrm{M}$, and $7.5 \mu \mathrm{M}$ of xanthine caused $98 \pm 2.1,60 \pm 9.7$, and $13 \pm 4 \%$ killing, respectively. The medium employed in these assays contained chloride $(119 \mathrm{mM})$; attempts to culture larvae in media that lacked chloride were unsuccessful. The addition of $10 \mu \mathrm{M}$ of iodide did not enhance the killing observed in the G-GO system (data not shown).

Larval uptake of $\left[{ }^{3} \mathrm{H}\right]$ deoxyglucose. Incubation of larvae in a medium that lacked glucose (PBS) but contained $\left[{ }^{3} \mathrm{H}\right]$ deoxyglucose resulted in an uptake of deoxyglucose by normal larvae that was linear with time (Fig. 2). The uptake was also dependent upon the number of larvae present; 10,000 larvae incorporated twice the amount detected in 5,000 larvae after $30 \mathrm{~min}$ of incubation (Fig. 2). Larvae incubated for $18 \mathrm{~h}$ in MEM/FCS that contained $5 \mathrm{mU} / \mathrm{ml}$ of glucose oxidase, then washed and incubated in PBS that con-

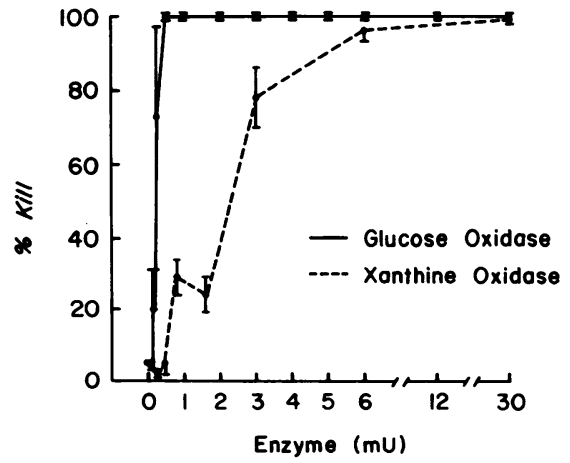

FIGURE 1 Killing of newborn $T$. spiralis larvae after incubation for $18 \mathrm{~h}$ in MEM/FCS with the addition of the indicated amounts of glucose oxidase or xanthine oxidase per $0.2-\mathrm{ml}$ assay well. The medium contained $5.6 \mathrm{mM}$ of glucose, and all xanthine oxidase assays were conducted with the addition of $750 \mu \mathrm{M}$ of xanthine per assay. Mean $\pm \mathrm{SE}$ of triplicates.

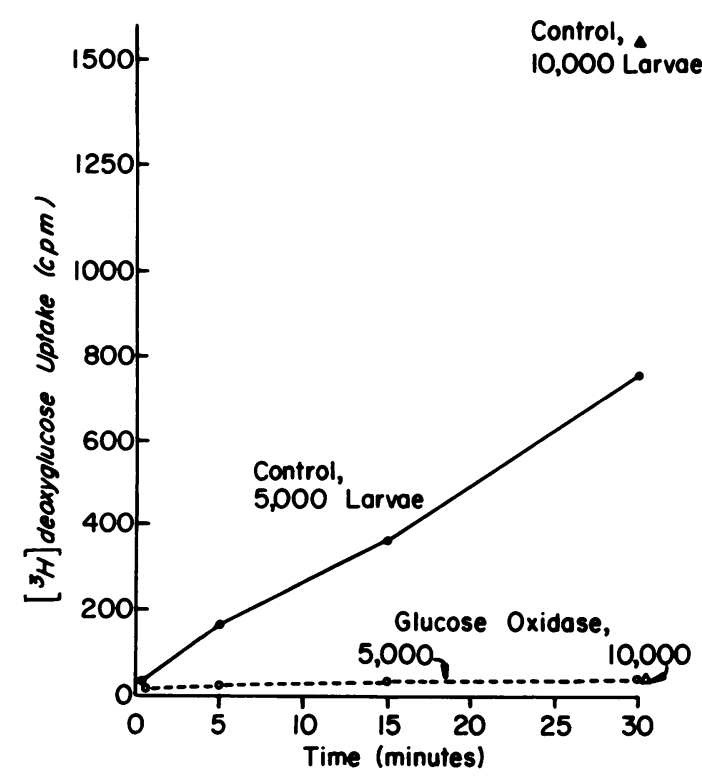

Figure 2 Uptake of $\left[{ }^{3} \mathrm{H}\right]$ deoxyglucose by newborn larvae and lack of uptake of larvae preincubated with G-GO. Larvae were incubated for $18 \mathrm{~h}$ in MEM/FCS (controls) or the same medium supplemented with $5 \mathrm{mU} / \mathrm{ml}$ glucose oxidase (equivalent to $1 \mathrm{mU}$ of glucose oxidase per microplate well), washed, incubated in $\left[{ }^{3} \mathrm{H}\right]$ deoxyglucose in PBS for the indicated times, washed, and the activity of the larval pellet was determined. Each point is the mean of closely agreeing duplicate determinations.

tained $\left[{ }^{3} \mathrm{H}\right]$ deoxyglucose, did not incorporate any deoxyglucose at any larval concentration.

Larval infectivity. Larvae incubated for $8 \mathrm{~h}$ in control medium or medium that contained $5 \mathrm{mU} / \mathrm{ml}$ of glucose oxidase were injected intravenously into mice such that each animal would receive 7,000 larvae. 1 mo later, the larvae that remained viable in the muscles of the mice were determined. From mice receiving control preparations, $2,250 \pm 315$ (mean $\pm \mathrm{SE}, n=6$ ) larvae were recovered, which is comparable to the recovery reported by other investigators $(24)$. No larvae were recovered from the mice given larvae incubated with glucose oxidase.

Effect of inhibitors. Catalase (1,400 U) markedly inhibited killing by G-GO (Table I). Boiled catalase or superoxide dismustase (SOD) did not alter killing activity. The effect of $10 \mu \mathrm{g} / \mathrm{ml}$ of SOD (twice the concentration that inhibits superoxide-mediated events in bactericidal assay systems [25]) was also examined at low concentrations $(0.5-2 \mathrm{mU})$ of xanthine oxidase; no effect on killing was observed (data not shown). Azide and cyanide did not inhibit killing. At a low concentration $(0.12 \mathrm{mU})$ of glucose oxidase, azide increased larval mortality from 27 to $100 \%$ (Table I).

Rate of killing by G-GO. Because catalase prevented larval death, the rate of killing was studied by adding catalase at varying times during incubation in 
TABLE I

Killing of Newborn Larvae by Glucose Oxidase: Effect of Inhibitors

\begin{tabular}{llc}
\hline $\begin{array}{l}\text { Glucose } \\
\text { oxidase }\end{array}$ & Putative inhibitors & Percent kill \\
\hline & & $\%$ \\
$12 \mathrm{mU}$ & None & $100 \pm 0(6)$ \\
$12 \mathrm{mU}$ & Catalase, $1,400 \mathrm{U}$ & $22 \pm 6.7(6)$ \\
$12 \mathrm{mU}$ & Boiled catalase & $100 \pm 0(3)$ \\
$12 \mathrm{mU}$ & SOD, $10 \mu \mathrm{g} / \mathrm{ml}$ & $100 \pm 0(6)$ \\
$12 \mathrm{mU}$ & Catalase $+\mathrm{SOD}$ & $27 \pm 11(6)$ \\
$1 \mathrm{mU}$ & None & $100 \pm 0(6)$ \\
$1 \mathrm{mU}$ & Azide, $5 \mathrm{mM}$ & $100 \pm 0(6)$ \\
$1 \mathrm{mU}$ & Cyanide, $5 \mathrm{mM}$ & $100 \pm 0(6)$ \\
$1 \mathrm{mU}$ & Catalase, $1,400 \mathrm{U}$ & $8 \pm 5.3(6)$ \\
$0.12 \mathrm{mU}$ & None & $27 \pm 4.9(3)$ \\
$0.12 \mathrm{mU}$ & Azide, $5 \mathrm{mM}$ & $100 \pm 0(3)$ \\
None & Catalase, $1,400 \mathrm{U}$ & $9 \pm 4.2(6)$ \\
None & Boiled catalase & $2 \pm 2.3(3)$ \\
None & SOD, $10 \mu \mathrm{g} / \mathrm{ml}$ & $4 \pm 3.3(6)$ \\
None & Cyanide, $5 \mathrm{mM}$ & $5 \pm 4.3(6)$ \\
None & Azide, $5 \mathrm{mM}$ & $7 \pm 4.9(6)$ \\
\hline
\end{tabular}

Incubation for $18 \mathrm{~h}$ in MEM/FCS (containing $5.6 \mathrm{mM}$ of glucose) with the indicated amounts of glucose oxidase and concentrations of inhibitors. Mean $\pm \mathrm{SE}$ of $(n)$ determinations.

G-GO and counting the surviving larvae after $18 \mathrm{~h}$ of incubation (Fig. 3). At $5 \mathrm{mU}$ glucose oxidase, percent killing increased steadily between 0 and $6 \mathrm{~h}$, by which time $100 \%$ mortality occurred.

Effects of leukocyte preparations. The effects of the addition of varying amounts of eosinophil or neu-

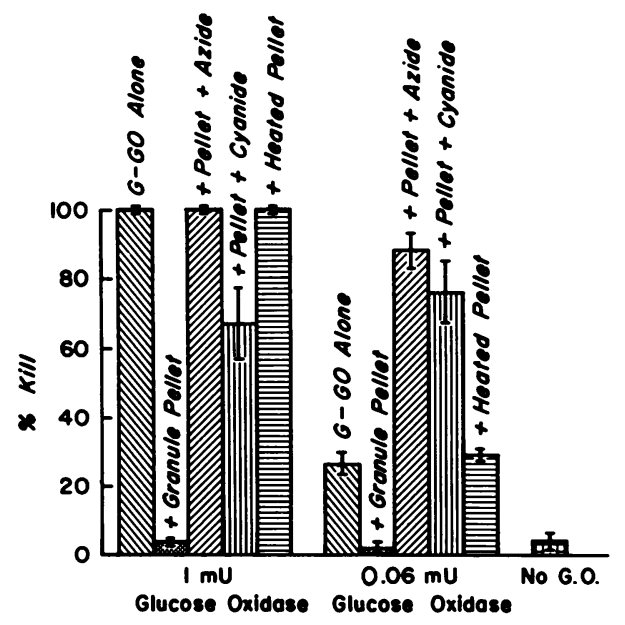

FIGURE 3 Rate of killing of larvae by incubation in G-GO. Larvae incubated in microplates in MEM/FCS with the addition of 1 or $5 \mathrm{mU}$ of glucose oxidase per assay well; total volume of $0.2 \mathrm{ml}$. Catalase $(1,400 \mathrm{U})$ was added at the indicated times. Plates were incubated for $18 \mathrm{~h}$, and the number of surviving larvae was determined. Mean $\pm S E$ of triplicates. trophil granule pellet preparations were studied. Previous studies have indicated killing of bacteria $(13,22,25)$ or mammalian tumor cells $(21)$ in peroxidase$\mathrm{H}_{2} \mathrm{O}_{2}$-halide systems that employed peroxidase concentrations that would be provided by $0.5 \mu \mathrm{g}$ protein of these preparations per $0.2-\mathrm{ml}$ assay. The assays employed concentrations of glucose oxidase immediately below $(0.06 \mathrm{mU})$ and above $(1 \mathrm{mU})$ the concentrations that produced larvicidal activity by G-GO alone (Figs. 4 and 5). None of the granule pellet preparations promoted larval killing by $0.06 \mathrm{mU}$ glucose oxidase. At high concentrations, both neutrophil and eosinophil pellet preparations inhibited killing by glucose oxidase. This inhibitory effect was reversed by azide or cyanide or by preheating $\left(100^{\circ} \mathrm{C}\right.$ for $\left.10 \mathrm{~min}\right)$ the granule pellet preparations (Fig. 5).

Effects of $p H$. Attempts to culture larvae in buffer systems (acetate, phosphate) other than bicarbonate$\mathrm{CO}_{2}$ (and other buffers present in MEM/FCS) were unsuccessful. Altering bicarbonate- $\mathrm{CO}_{2}$ ratios with culture in MEM/FCS could produce a minimum $\mathrm{pH}$ of 6.9. The addition of small quantities of hydrochloric or acetic acid to MEM/FCS allowed production of lower $\mathrm{pH}$ with larval survival. Although this reduced the $\mathrm{pH}$ stability of the culture medium, it allowed study of larval killing at $\mathrm{pH} 4.5,5.7,6.6,6.9$, 7.1 , and $7.3 \mathrm{pH}$ measured at the end of an $18 \mathrm{~h}$ incubation). Addition of eosinophil or neutrophil granule pellet preparations ( $1 \mu \mathrm{g}$ protein/assay) did not significantly enhance the killing achieved by G-GO alone at any $\mathrm{pH}$ examined (data not shown).

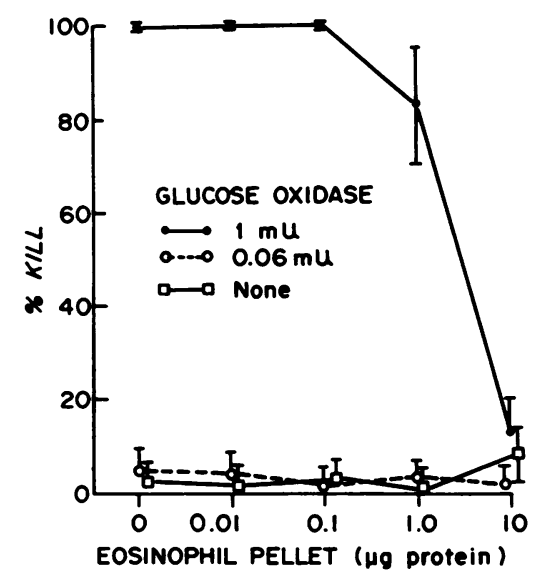

Figure 4 Effects of eosinophil granule pellet on larval killing by incubation for $18 \mathrm{~h}$ in G-GO. Glucose oxidase added in amounts immediately below $(0.06 \mathrm{mU} / \mathrm{test})$ and above ( $1 \mathrm{mU} / \mathrm{test}$ ) the concentration producing larval killing by G-GO in the absence of leukocyte preparations. Eosinophil granule pellet preparation (peroxidase content 5,800 $\mathrm{U} / \mathrm{mg}$ protein) added at the amounts indicated per $0.2-\mathrm{ml}$ assay. Similar data were obtained in parallel experiments employing neutrophil granule preparations (data not shown). Points are mean $\pm \mathrm{SE}$ of triplicates. 


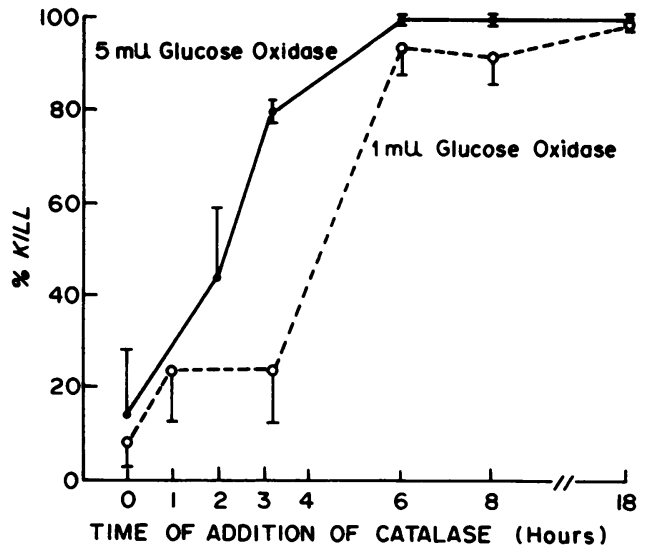

FIGURE 5 Inhibition of larvicidal activity of G-GO by granule pellet preparation. Reversal by $5 \mathrm{mM}$ of cyanide or azide or by preheating the granule preparation. Addition of $25 \mu \mathrm{g}$ (to assays with $1 \mathrm{mU}$ of glucose oxidase [G.O.] or $2.5 \mu \mathrm{g}$ (to assays with $0.06 \mathrm{mU}$ of glucose oxidase) of neutrophil granule preparation that contained $1,450 \mathrm{U}$ peroxidase/mg protein. Hemeprotein inhibitors or preheating similarly reversed the inhibitory effects of eosinophil granule preparations (data not shown). Mean $\pm S E$ of three to six determinations.

Bactericidal effects of these assay conditions. The microtiter assay employed in these studies differed significantly from standard bacterial killing assays usually employed to study the bactericidal activity of leukocyte lysosomal enzymes and oxidative substances. Larval culture employed a complete medium that contained chloride and serum protein. Bactericidal activities of glucose oxidase alone and with neutrophil or eosinophil pellet preparations in the presence of chloride and iodide were examined employing culture in MEM/FCS at $\mathrm{pH} 7.4$ and, for comparison, using $0.1 \mathrm{M}$ of acetate buffer at $\mathrm{pH}$ 5.0. With both assay conditions, over $60 \mathrm{mU}$ glucose oxidase was required to achieve $90 \%$ killing of bacteria. However, the effects of leukocyte granule preparations differed markedly in the two systems. In the absence of serum protein, granule preparations enhanced the bactericidal activity of G-GO (over $99.9 \%$ killing with $2 \mathrm{mU}$ of glucose oxidase). In the presence of $10 \%$ serum, G-GO bactericidal activity was decreased by leukocyte granule preparations (data not shown).

\section{DISCUSSION}

The microtiter plate assay was employed in these studies to determine larval killing by direct examination and quantitation of surviving, motile larvae. However, unlike the assay that employed whole cells $(2,5)$, not all of the larvae were lysed in these cell-free systems. Killed larvae were immobile and highly refractile, conditions that have been used in similar assay systems to indicate larval death (7). Confirma- tion that such immobile larvae were dead was obtained in three ways: (a) "Dead" larvae did not resume motility after washing, resuspending, and incubating in fresh medium. (b) Whereas control larvae took up $\left[{ }^{3} \mathrm{H}\right]$ deoxyglucose in a time- and concentration-related manner, larvae incubated with G-GO demonstrated no uptake of deoxyglucose. (c) Normal newborn larvae survived intravenous injection into normal mice and achieved muscle encystment. When larvae incubated with G-GO were injected, none survived.

The newborn (migratory phase) larvae of $T$. spiralis were highly susceptible to oxidative products generated during the reaction of G-GO or X-XO. Whereas $>60 \mathrm{mU}$ of glucose oxidase were required to kill over $90 \%$ of $S$. aureus in a standard bactericidal assay, $100 \%$ killing of larvae occurred with a concentration of $2.5 \mathrm{mU} / \mathrm{ml}(0.5 \mathrm{mU} /$ assay $)$ glucose oxidase. Concentrations of $60-200 \mathrm{mU} / \mathrm{ml}$ of G-GO or xanthine oxidase (plus xanthine or purine) have been required to kill bacteria $(26,27)$ or mammalian cells $(28)$ in previous studies. However, larval killing occurred more slowly than the killing of bacteria. Whereas most of the killing of bacteria by leukocytes (or the G-GO system constructed to mimic whole-cell killing) occurs within $1 \mathrm{~h}$, killing of larvae by leukocytes (5) or the parallel G-GO system required at least $6 \mathrm{~h}$.

Killing of larvae appeared to be a result of direct toxicity by hydrogen peroxide. In both the whole-cell system (5) and the G-GO or X-XO assays, killing was markedly inhibited by catalase but not by boiled catalase or SOD. The lack of effect of SOD strongly suggests that superoxide, singlet oxygen (29), or hydroxyl radicals (30) did not contribute significantly to the larvicidal event. Also, a combined peroxidase$\mathrm{H}_{2} \mathrm{O}_{2}$-halide mechanism, thought important in leukocyte bactericidal activity (13), could not be demonstrated. Addition of varying concentrations of eosinophil or neutrophil granule pellet preparations (containing peroxidase) did not enhance the killing by hydrogen peroxide generator systems. Indeed, at higher concentrations, the leukocyte preparations inhibited killing by G-GO. This inhibitory effect was blocked by azide or cyanide and may have been a result of peroxidase-mediated consumption of $\mathrm{H}_{2} \mathrm{O}_{2}$ by reaction with serum proteins in the culture medium $(31,32)$. Serum protein similarly inhibited the bactericidal activity of the peroxidase- $\mathrm{H}_{2} \mathrm{O}_{2}$-halide system. This does not challenge the role of this system in bacterial killing by phagocytizing leukocytes because phagocytosis involves tight and complete enclosure of the bacterium within the phagosome (33) with presumably little, if any, inclusion of serum protein. However, the effect of serum protein may be important during the killing of extracellular targets by leukocytes. It could be argued that leukocytes be- 
come tightly adherent to such targets; local degranulation could provide a serum-free microenvironment at the cell-target interface where the peroxidase$\mathrm{H}_{2} \mathrm{O}_{2}$-halide mechanism would be active. This hypothesis is unproven and is not supported by available data. Extracellular killing of fungi (34) or mammalian cells (28) by the peroxidase- $\mathrm{H}_{2} \mathrm{O}_{2}$-halide mechanism has only been demonstrable in medium that lacked serum protein. Also, we were unable to demonstrate involvement of this mechanism during larval killing by intact leukocytes (5). Finally, the marked susceptibility of newborn larvae of $T$. spiralis to direct toxicity by $\mathrm{H}_{2} \mathrm{O}_{2}$ was sufficient to provide the larvicidal mechanism without necessary involvement of the peroxidase- $\mathrm{H}_{2} \mathrm{O}_{2}$-haline system.

\section{ACKNOWLEDGMENTS}

We wish to thank Dr. Charles E. McCall and Dr. Lawrence R. DeChatelet for many helpful discussions and Ms. June Heflin for preparation of the manuscript.

This work was supported, in part, by a grant from the National Foundation-March of Dimes.

\section{REFERENCES}

1. Butterworth, A. E., J. R. David, D. Franks, A. A. F. Mahmoud, P. H. David, R. F. Sturrock, and V. Houba. 1977. Antibody-dependent eosinophil-mediated damage to Cr-labeled schistosomula of Schistosoma mansoni: damage by purified eosinophils. J. Exp. Med. 145: 136149.

2. Kazura, J. W., and D. I. Grove. 1978. Stage-specific antibody-dependent eosinophil-mediated destruction of Trichinella spiralis. Nature (Lond.). 273: 588-589.

3. Mahmoud, A. A. F., K. S. Warren, and P. A. Peters. 1975. A role for the eosinophil in acquired resistance to Schistosoma mansoni infection as determined by antieosinophil serum. J. Exp. Med. 142: 805-813.

4. Grove, D. I., A. A. F. Mahmoud, and K. S. Warren. 1977. Eosinophils and resistance to Trichinella spiralis. J. Exp. Med. 145: 755-759.

5. Bass, D. A., and P. Szejda. 1979. Eosinophils versus neutrophils in host defense. Killing of newborn larvae of Trichinella spiralis by human granulocytes in vitro. $J$. Clin. Invest. 64: 1415-1422.

6. Hsu, S. Y. L., H. F. Hsu, P. Isacson, and H. F. Cheng. 1977. In vitro Schistosomulicidal effect of immune serum and eosinophils, neutrophils, and lymphocytes. $J$. Reticuloendothel. Soc. 21: 153-162.

7. Dean, D. A., R. Wistar, and K. D. Murrell. 1974. Combined in vitro effects of rat antibody and neutrophilic leukocytes on schistosomula of Schistosoma mansoni. Am. J. Trop. Med. Hyg. 23: 420-428.

8. Capron, A., J. P. Dessaint, M. Capron, and H. Bazin. 1975. Specific IgE antibodies in immune adherence of normal macrophages to Schistosoma mansoni schistosomules. Nature (Lond.). 253: 474-475.

9. Mahmoud, A. A. F., P. A. S. Peters, R. H. Civil, and J. S. Remington. 1979. In vitro killing of schistosomula of Schistosoma mansoni by BCG and C. Paroumactivated macrophages. J. Immunol. 122: 1655-1657.

10. Capron, M., A. Capron, G. Torpier, H. Bazin, D. Bout, and M. Joseph. 1978. Eosinophil-dependent cytotoxicity in rat schistosomiasis. Involvement of $\operatorname{IgG}_{2 \mathrm{a}}$ antibody and role of mast cells. Eur. J. Immunol. 8: 127-133.

11. David, J. R., A. E. Butterworth, H. G. Remold, P. H. David, V. Houba, and R. F. Sturrock. 1977. Antibodydependent, eosinophil-mediated damage to 51-Cr-labelled schistosomula of Schistosoma mansoni: effect of metabolic inhibitors and other agents which alter cell function. J. Immunol. 118: 2221-2229.

12. Butterworth, A. E., D. L. Wassom, G. J. Gleich, D. A. Loegering, and J. R. David. 1979. Damage to schistosomula of Schistomona mansoni induced directly by eosinophil major basic protein. J. Immunol. 122: 221-229.

13. Klebanoff, S. J. 1967. Iodination of bacteria: a bactericidal mechanism. J. Exp. Med. 126: 1063-1076.

14. Dennis, D. T., D. D. Despommier, and M. David. 1970. Infectivity of newborn larva of Trichinella spiralis in the rat. J. Parasitol. 56: 974-977.

15. Bass, D. A., L. R. DeChatelet, and C. E. McCall. 1978. Independent stimulation of motility and the oxidative metabolic burst of human polymorphonuclear leukocytes. J. Immunol. 121: 172-178.

16. DeChatelet, L. R., L. C. McPhail, D. Mullikin, and C. E. McCall. 1975. An isotopic assay for NADPH oxidase activity and some characteristics of the enzyme from human polymorphonuclear leukocytes. J. Clin. Invest. 55: 714721 .

17. DeChatelet, L. R., P. S. Shirley, L. C. McPhail, C. C. Huntley, H. B. Muss, and D. A. Bass. 1977. Oxidative metabolism of the human eosinophil. Blood. 50: 525535.

18. Lowry, O. H., N. J. Rosebrough, A. L. Farr, and R. J. Randall. 1951. Protein measurement with the Folin phenol reagent. J. Biol. Chem. 193: 265-275.

19. Migler, R., and L. R. DeChatelet. 1978. Human eosinophilic peroxidase: biochemical characterization. Biochem. Med. 19: 16-26.

20. Worthington Enzyme Manual. 1972. Worthington Biochemical Corp., Freehold, N. J. 43.

21. Clark, R. A., S. J. Klebanoff, A. B. Einstein, and A. Fefer. 1975. Peroxidase- $\mathrm{H}_{2} \mathrm{O}_{2}$-halide system: cytotoxic effect on mammalian tumor cells. Blood. 45: 161-170.

22. Migler, R., L. R. DeChatelet, and D. A. Bass. 1978. Human eosinophilic peroxidase: role in bactericidal activity. Blood. 51: 445-456.

23. Fridovich, I. 1970. Quantitative aspects of the production of superoxide radical by milk xanthine oxidase. $J$. Biol. Chem. 245: 4053-4057.

24. Perrudet-Badoux, A. P., and R. A. Binaghi. 1978. Immunity against newborn Trichinella spiralis larvae in previously infected mice. J. Parasitol. 64: 187-189.

25. Klebanoff, S. J. 1974. Role of the superoxide anion in the myeloperoxidase-mediated antimicrobial system. J. Biol. Chem. 249: 3724-3728.

26. Babior, B. M., J. T. Curnette, and R. S. Kipnes. 1975. Biological defense mechanisms. Evidence for the participation of superoxide in bacterial killing by xanthine oxidase. J. Lab. Clin. Med. 85: 235-244.

27. Ismail, G., W. D. Sawyer, and W. S. Wegener. 1977. Effect of hydrogen peroxide and superoxide radical on viability of Neisseria gonorrheae and related bacteria. Proc. Soc. Exp. Biol. Med. 155: 264-269.

28. Clark, R. A., and S. J. Klebanoff. 1975. Neutrophil mediated tumor cell cytotoxicity: role of the peroxidase system. J. Exp. Med. 141: 1442-1447.

29. Kellog, E. W., III, and I. Fridovich. 1975. Superoxide, hydrogen peroxide and singlet oxygen in lipid peroxidation by a xanthine oxidase system. J. Biol. Chem. 250: 8812-8817. 
30. Beauchamp, C., and I. Fridovich. 1970. A mechanism for the production of ethylene from methional. The generation of hydroxyl radical by xanthine oxidase.J. Biol. Chem. 245: 4641-4646.

31. Klebanoff, S. J., and C. B. Hamon. 1972. Role of myeloperoxidase-mediated antimicrobial systems in intact leukocytes. J. Reticuloendothel. Soc. 12: 170-196.

32. Odeberg, H., T. Olofsson, and I. Olsson. 1974. Myeloperoxidase-mediated extracellular iodination during phagocytosis in granulocytes. Scand. J. Haematol. 12: $155-160$.
33. Griffin, F. M., Jr., J. A. Griffin, J. E. Leider, and S. C. Silverstein. 1975. Studies on the mechanism of phagocytosis. I. Requirements for circumferential attachment of particle-bound ligands to specific receptors on the macrophage plasma membrane. J. Exp. Med. 143: 12631282.

34. Diamond, R. D., and R. Krzesicki. 1978. Mechanisms of attachment of neutrophils to Candida albicans pseudohyphae in the absence of serum, and of subsequent damage to pseudohyphae by microbicidal processes of neutrophils in vitro. J. Clin. Invest. 61: 360-369. 